\title{
PERAN MEDIA RELATIONS TERHADAP KEBERHASILAN PROGRAM PROVOCATIVE PROACTIVE DI PT MEDIA TELEVISI INDONESIA (METRO TV)
}

\author{
Marta Sanjaya; Ariesza Sekarayu Larasati \\ Marketing Communication, Faculty of Economic and Communication, BINUS University \\ Jln. K.H. Syahdan No. 9, Palmerah, Jakarta Barat 11480 \\ marta.sanjaya@gmail.com
}

\begin{abstract}
This article aims to determine whether the Provocative Proactive (PP) program on Metro TV proactive is known by Indonesian people, to explain how the media selection strategy for Provocative Proactive program is, and to explain the program on Metro TV can be written and known by the press or reporters (external PR). The method used was descriptive qualitative approach to analyze the existing problems by presentation of information from the data collected through the company's internal analysis of the results of in-depth interviews and field observations regarding activities in the company. The results showed that duties and functions of public relations are as a motor for better co-operation with external and internal parties relating to Provocative Proactive program. The PR and Promotion Departments were turned out to help the success of the PP program, in addition to various roles and hardworks of the Producer and the creative team. Based on the observations, the role of Metro TV's PR and Promotion Departments in conducting media relations through cooperation with the media both print and electronic media in an effort to have Provocative Proactive widely known by the public is through cooperation with various mass media, implementation of mass media selection strategies, and introducing Provocative Proactive Program broadly.
\end{abstract}

Keywords: roles of media relations, public relations, mass media selection strategies

\begin{abstract}
ABSTRAK
Penelitian yang berjudul "Peran Media Relations Pada Program Provocative Proactive di PT. Media Televisi Indonesia (Metro TV)”, bertujuan untuk mengetahui apakah program provocative proactive di Metro TV dikenal luas oleh masyarakat Indonesia, menjelaskan bagaimana strategi pemilihan media terhadap program provocative proactive serta menjelaskan bahwa program provocative proactive di Metro TV bisa ditulis dan dikenal oleh pers atau wartawan (eksternal PR). Metode penelitian yang digunakan adalah pendekatan deskriptif kualitatif untuk menganalisis permasalahan yang ada dengan penyajian informasi data yang terkumpul dari pihak internal perusahaan melalui analisis hasil wawancara mendalam (in-depth interview) dan observasi mengenai kegiatan dalam perusahaan. Hasil penelitian menunjukkan bahwa tugas dan fungsi PR adalah sebagai motor untuk agar terjalin kerja sama baik dengan pihak ekternal maupun internal yang terkait dengan program Provocative Proactive. Departemen $P R$ dan Promosi ternyata membantu suksesnya program PP, selain berbagai peran dan kerja keras Produser PP serta tim kreatif. Berdasarkan hasil pengamatan terhadap peran Departemen PR dan Promosi Metro TV dalam melaksanakan kegiatan media relations melalui jalinan kerja sama dengan berbagai media baik cetak maupun elektronik agar program Provocative Proactive dapat dikenal luas oleh masyarakat, di antaranya melalui jalinan kerja sama dengan berbagai media massa, penerapan strategi pemilihan media massa, dan pengenalan program PP secara luas.
\end{abstract}

Kata kunci: peran media relations, hubungan masyarakat, strategi pemilihan media massa 


\section{PENDAHULUAN}

Media Relations adalah relasi yang dibangun dan dikembangkan dengan media untuk menjangkau publik guna meningkatkan pencitraan, kepercayaan, kekuatan, dan tercapainya tujuantujuan individu maupun organisasi/perusahaan. Sementara itu, fungsi media relations adalah untuk meningkatkan citra perusahaan, meningkatkan kepercayaan publik, meningkatkan point of selling serta membantu perusahaan keluar dari komunikasi krisis, dan meningkatkan relasi dari beragam publik. Vivian (2008) menyatakan bahwa media relations pada bagian Public Relations memiliki paling tidak tiga tanggung jawab fungsional. Pertama, relasi eksternal, bentuk relasi ini mengoptimalkan komunikasi dengan pihak-pihak di luar perusahaan. Pihak-pihak inilah yang nanti menjadi acuan seberapa kuat citra perusahaan di luar. Stakeholder, konsumen, pemerintah, dan sebagainya adalah pihak yang bisa membentuk opini publik terhadap perusahaan. Kedua, relasi internal, komunikasi ini dilakukan untuk menjaga hubungan yang harmonis dan dinamis dengan melibatkan pihak internal sendiri. Sebut saja para karyawan, manajer, pemegang saham, dan kelompok yang berada dalam lingkup perusahaan. Mereka semua memegang roda berjalannya perusahaan. Ketiga, relasi media, relasi ini dijalin perusahaan yang melakukan komunikasi dengan pihak media massa. Hubungan ini harus dibina agar tidak ada miscommunication kemudian hari. Perusahaan perlu berelasi dengan media dalam mencari dan memberikan informasi guna mencapai tujuan perusahaan. Media pun harus dimanfaatkan agar tidak ada informasi-informasi yang beredar yang bisa merusak citra perusahaan.

Dengan penjelasan tersebut, keberadaan media relations diharapkan mampu menanggulangi krisis komunikasi. Dalam suatu perusahaan jika terjadi hambatan saluran komunikasi, akan terjadi krisis komunikasi. PR harus dimanfaatkan sedemikian rupa agar mampu mengoptimalkan semua saluran komunikasi yang ada. Macetnya saluran komunikasi menimbulkan berbagai dampak yang bisa kompleks karena saluran komunikasi merupakan jalan perputaran informasi. Apa jadinya jika saluran komunikasi ini macet, dapat diprediksi bahwa akan banyak terjadi bencana miscommunication dalam perusahaan. PR harus mampu mengelola seoptimal mungkin fungsi dari media relations itu sendiri.

Perkembangan teknologi dan pengaruhnya terhadap bentuk-bentuk media massa memberikan pengaruh yang berarti bagi perusahaan. Liputan yang baik di media akan memberikan pencitraan yang baik pula bagi perusahaan, meningkatkan kepercayaan pelanggan dalam memakai produk perusahaan, dan akhirnya menumbuhkan minat pemodal untuk menginvestasikan modalnya pada perusahaan. Aktivitas Public Relations inilah yang menjalin relasi dengan media dan mendapatkan kepercayaan dari liputan media.

Hal tersebut membuktikan bahwa peranan media relation memberikan pengaruh terhadap segala aktivitas internal maupun eksternal dari perusahaan itu sendiri. Jika dikaitkan dengan hubungannya dengan publikasi suatu kegiatan yang berlangsung di sebuah stasiun televisi, media relation memiliki pengaruh yang sangat relevan terhadap proses berlangsungnya kegiatan publikasi tersebut, terlebih pada cara mempublikasi ataupun melakukan tindak promosi suatu program yang ditampilkan dari sebuah stasiun TV. Media relation adalah sebagai getting awareness terhadap suatu program tersebut agar sampai kepada audience, sehingga audience dapat merasa senang dan puas sehingga dapat memberikan loyalitasnya kepada program yang ditampilkan dari sebuah stasiun tv tersebut. Dalam hal ini, penelitian mengangkat sebuah program di Metro TV, yang di dalamnya media relations memberikan perannya dalam keberhasilan program ini yaitu program Provocative Proactive.

Provocative Proactive hadir di layar kaca televisi. Sebuah sajian baru yang segar menghibur, kaya pengetahuan dan informasi. Tayangan "live” setiap Kamis malam pukul 22.05-23.00, bekerja sama dengan MetroTV seiring dengan misi baru yang dipahami bersama, "knowledge to elevate". Tayangan terbagi atas 2 bagian: bagian pertama Provocative Proactive membahas isu politik dan isu kini, wawancara dengan tokoh penting juga memberi kesempatan bagi kaum muda untuk aktif 
berpartisipasi dalam Citizen Journalism dan Say What? Bagian kedua adalah Warung Kopi. Sebuah talkshow dengan konsep situasi komedi dengan 4 host yang mewakili 4 lapisan masyarakat. Pandji Pragiwaksono sebagai pegawai kantoran kelas menengah, Raditya Dika mewakili suara mahasiswa, Ronal Surapradja mewakili kaum rakyat kebanyakan, J.Flow mewakili kaum anak muda yang penuh gaya, dan Andari yang merupakan tokoh tambahan mewakili suara perempuan. Segmen ini mengundang tokoh penting disesuaikan dengan isu hangat yang sedang berlangsung. Segmen dikemas masing-masing dalam 30 menit durasi dan dirangkum bersama tim pemuda kreatif Andi Bachtiar, Pangeran Siahaan, Iman Sjafei, Naufal Fileindi, Shani Budi, dan Khamila Sari Mulia.

Bersama-sama para pemuda ini memiliki tujuan sederhana, membuat yang yang tidak tahu menjadi tahu, yang tidak peduli menjadi peduli. Program ini menyajikan edukasi politik kepada anak muda Indonesia, yang jelas memiliki kekuatan politik yang besar baik dalam pemilu langsung presiden maupun legislatif. Para pemuda ini percaya bahwa memiliki sebuah bangsa yang mampu memanfaatkan kekuatan politiknya dengan cara berbekal pemahaman politik yang baik.

Setiap minggu, mereka akan bertemu di "Warung Kopi" dan membahas isu-isu panas. METRO TV, Setiap Kamis, pukul 22.00 WIB - ketika tayang perdana pada 5 Agustus lalu, Provocative Proactive (PP) langsung mendapat tanggapan positif. Program ini membahas berita dan kabar terpanas dalam satu minggu. Sebuah kemasan yang berbeda ditawarkan PP. Program ini menghadirkan deretan host antara lain Pandji Pragiwaksono, Ronal Surapradja, Raditya Dika, dan J Flow. Tayangannya dibagi dua bagian besar. Pertama adalah berita. Pandji membawakan berita-berita selama satu pekan yang panas, disampaikan dengan gaya khas Pandji. Bagian kedua talkshow, dengan nama "Warung Kopi". Alasan pemilihan nama karena warung kopi adalah bagian dari budaya Indonesia. Orang-orang Indonesia senang sekali bersosialisasi di tempat itu dengan ngobrol dan nongkrong, mulai dari berita politik hingga isu-isu konspirasi yang makin hot ketika diperdebatkan dengan masing-masing host memainkan peran masing-masing. Mereka mewakili berbagai golongan di masyarakat. Mulai dari kelas pekerja (Pandji), mahasiswa (Dika), rakyat jelata (Ronal), dan orang kaya yang peduli bangsa (J Flow).

Acara Provocative Proactive sendiri merupakan ide tunggal Pandji, yang ditawarkan dalam bentuk proposal ke Metro. Berikut kutipan yang didapat dari blog Pandji: Betul bahwa acara ini konsepnya datang dari program radio, tapi versi TV-nya cuma mengadaptasi konsep "Aktif memprovokasi pemikiran sendiri". Pengaruh terakhir adalah sebuah serial TV berjudul "Entourage" yang di dalamnya ada 4 tokoh yg mewakili 4 karakter laki laki, maka lahirlah acara PP TV Show, 40\% berita, 60\% talkshow, 100\% usaha untuk mengajak anak muda di Indonesia untuk lebih sadar keadaan bangsa lewat berita, dan edukasi politik. Provocative Proactive sendiri adalah judul album perdana Pandji Pragiwaksono, acara radionya juga dan sekarang jadi TV Show di Metro. Berdasarkan penjelasan, penulisan ini mengambil judul Peran Media Relations terhadap Keberhasilan Program Provocative Proactive di PT. Media Televisi Indonesia (Metro TV).

\section{Landasan Teori}

\section{Komunikasi}

Komunikasi merupakan suatu interaksi antarpribadi, antarkelompok yang dilakukan baik secara verbal maupun nonverbal, langsung maupun tidak langsung. Dalam komunikasi sendiri berisi berbagai macam hal yang akan dijadikan bahan untuk berkomunikasi itu sendiri. Ruslan (2006:17) mempunyai pendapat tentang komunikasi yakni: "Komunikasi adalah penyampaian informasi, gagasan, emosi, keterampilan dan sebagainya dengan menggunakan lambang-lambang atau kata-kata, gambar, bilangan, grafik dan lain-lain. Kegiatan atau proses penyampaiannya biasanya dinamakan komunikasi.” Kemudian menurut Berger dan Chaffee, yang dikutip Sendjaja (2002:116), komunikasi adalah: "Pengetahuan tentang peristiwa komunikasi yang diperoleh melalui suatu penelitian tentang 
sistem, proses dan pengaruhnya yang dilakukan secara rasional dan sistematik, serta kebenarannya dapat diuji dan digeneralisasikan.” Dengan demikian ditarik simpulan bahwa komunikasi adalah salah satu bentuk interaksi atau jalinan yang dilakukan antara seseorang ataupun kelompok yang di dalamnya berisi tentang informasi, ide, emosi, dan sebagainya. Kemudian komunikasi itu akan memberikan pengaruh berupa respon timbal balik.

\section{Public Relations}

Public relations merupakan salah satu kegiatan komunikasi dua arah antara organisasi atau perusahaan dengan publik, dalam mendukung fungsi dan tujuan manajemen dengan meningkatkan kerjasama dan pemenuhan kepentingan bersama antara keduanya. Organisasi public relations nasional dan internasional juga telah menyusun definisi yang cukup luas untuk diterapkan. Definisi ini meliputi berikut ini: "Public relations adalah usaha sengaja, terencana, dan tidak pernah mati untuk menetapkan dan memelihara saling pengertian antara sebuah organisasi dan masyarakatnya.” (British Institute of Public Opinion, yang definisinya juga telah diikuti di sejumlah Negara Persemakmuran) "Public relations adalah suatu usaha sengaja dan sesuai hukum untuk mencapai pemahaman dan membina serta memelihara kepercayaan di antara masyarakat umum atas dasar riset sistematis”. "Public Relations adalah juga sebagai usaha manajerial secara sistematis dan tidak pernah berhenti yang digunakan sebagai alat bagi organisasi swasta dan pemerintah untuk membina pengertian, simpati, dukungan di lingkaran masyarakat yang diperkirakan akan berhubungan dengan mereka.”

\section{METODE PENELITIAN}

Teknik pengumpulan data merupakan langkah yang paling strategis dalam penelitian karena tujuan utama dari penelitian adalah mendapatkan data. Tanpa menegetahui teknik pengumpulan data, maka tidak akan didapatkan data yang memenuhi standar data yang ditetapkan. Pengumpulan data dapat dilakukan dalam berbagai setting. Data dapat dikumpulkan pada setting alamiah, pada laboratorium dengan metode eksperimen, di rumah dengan berbagai responden, pada suatu seminar, diskusi, di jalan dan sebagainya. Menurut Sugiyono (2009), pada gambar berikut terlihat bahwa secara umum terdapat empat macam teknik pengumpulan data.

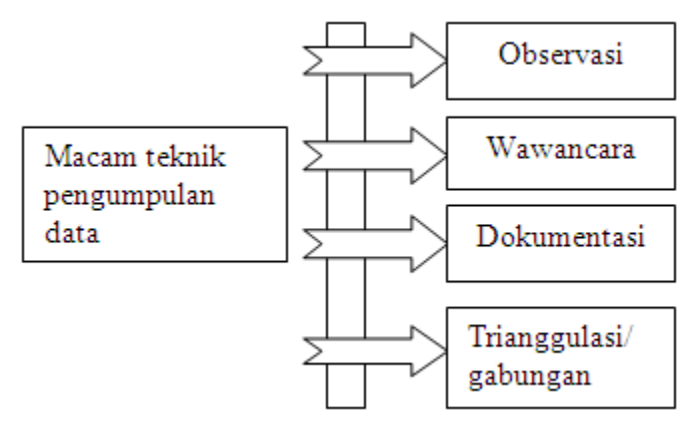

Gambar 1 Teknik Pengumpulan Data

(Sumber: Sugiyono, 2009:409)

Pada penelitian ini teknik pengumpulan data yang dikumpulkan penulis berasal dari dua sumber data. Pertama adalah data primer dengan (a) wawancara mendalam; Burhan (2007:108), menyatakan: "Wawancara mendalam adalah proses memperoleh keterangan untuk tujuan penelitian dengan cara tanya jawab sambil bertatap muka antara pewawancara dengan informan atau orang yang diwawancarai dengan atau tanpa menggunakan pedoman (guide) wawancara." Penelitian 
menggunakan wawancara terstruktur atau wawancara mendalam dengan menyiapkan terlebih dahulu bahan wawancara dan melaksanakan wawancara terhadap para responden secara tertulis. Dengan demikian para responden dapat melihat pertanyaannya secara saksama dan kemudian mengisi jawaban (Sugiyono, 2009). Wawancara dilakukan dengan Departemen Public Relation and Promotion Metro TV, yaitu Promotion Head, Public Relation Manager, dan Produser Provocative Proactive. Lalu, (b) pengamatan (observasi); selain melakukan wawancara terhadap beberapa narasumber, kemudian dilakukan observasi. Seperti yang dikemukakan oleh Marshall (dalam Sugiyono, 2009) melalui observasi peneliti tentang perilaku, dan makna dari perilaku tersebut.

Kedua adalah data sekunder. Menurut Ruslan (2006), data sekunder merupakan data penelitian yang diperoleh secara tidak langsung melalui media perantara, umumnya berupa bukti, catatan, atau laporan historis yang disusun dalam bentuk arsip atau dokumen yang diperoleh antara lain melalui (a) studi kepustakaan dengan membaca dan mempelajari buku teks, makalah maupun bacaan lainnya serta diktat, makalah kuliah yang menjadi referensi dalam penulisan skripsi; dan (b) Internet. Analisis dokumen yang dilakukan penulis berasal dari banyak sumber mengenai Metro TV beserta kegiatan dari Departemen Promosi dan PR serta program Provocative Proactive yang berkaitan dengan judul yang diangkat.

Dalam mencari alternatif pemecahan masalah penelitian ini yaitu Peran Media Relations Terhadap Keberhasilan Program Provocative Proactive di PT. Media Televisi Indonesia (Metro TV) dan untuk mengetahui secara lebih jelasnya maka penulis melakukan penelitian ini melalui metode penelitian kualitatif deskriptif dengan teknik pengumpulan data wawancara dan observasi langsung di departemen Promosi, Public Relations serta produser program provocative proactive di PT. Media Televisi Indonesia (Metro tv). Melalui wawancara penulis mendapatkan informasi yang digali dari sumber data langsung melalui percakapan atau tanya jawab. Wawancara dilakukan dengan Head of Promotion Departement sebagai key informan dan Manager Public Relations Metro TV sebagai informan satu serta serta produser program provocative proactive sebagai informan kedua.

Penulis juga melakukan pengamatan langsung di Metro TV. Walaupun penulis tidak terlibat secara langsung dalam Peran Media Relations Terhadap Keberhasilan Program Provocative Proactive di Metro TV. Tetapi peneliti sering kali mendapat petunjuk melakukan observasi untuk memperkaya data agar dapat memecahkan dalam permasalahn yang ada sehingga dapat mengetahui apakah program provocative proactive dikenal luas oleh masyarakat Indonesia, dapat menjelaskan strategi pemilihan media terhadap program Provocative Proactive serta mengetahui program Provocative Proactive bisa ditulis dan dikenal oleh pers atau wartawan (eksternal PR).

Dalam hal ini penulis menggunakan reduksi data, yang berarti merangkum, memilih hal-hal yang pokok, memfokuskan pada hal-hal yang penting penting serta dicari tema dan polanya, yang mana data yang diperoleh dalam lapangan ditulis dalam bentuk uraian atau laporan perinci. Jadi laporan lapangan sebagai bahan "mentah" disingkatkan, direduksi, disusun lebih sistematis, ditonjolkan pokok-pokok yang penting, diberi susunan yang lebih sistematis sehingga lebih mudah dikendalikan. Dalam mereduksi data, setiap peneliti akan dipandu oleh tujuan yang akan di capai, karena tujuan utama dari penelitian kualitatif ini adalah pada temuan sehingga data yang direduksi memberi gambaran yang lebih tajam tentang hasil pengamatan, juga mempermudah peneliti untuk mencari data bila diperlukan.

Adapun hal-hal yang telah dilakukan peneliti dalam menganalisis laporan hasil penelitian adalah memfokuskan pada peranan Media Relations terhadap keberhasilan program Provocative Proactive (PP) di Metro TV, kemudian memperoleh data dan semua informasi berupa hasil wawancara ataupun dokumentasi (plan Media Relations terahadap program PP, share and rating) yang terkait dengan hasil laporan penelitian tentang peranan Media Relations terhadap keberhasilan program provocative proactive di Metro TV baik itu dari Departemen Promosi, Departemen Public Relations serta Produser Program PP, sehingga dari hasil penelitian menunjukkan bahwa peranan 
Media Relations khususnya pada program PP ini mencapai keberhasilan dan telah dikenal luas oleh masyarakat yang dilihat dari peran kerja yang baik Departemen Promosi, Departemen Public Relations serta Produser Program PP dalam mencapai keberhasilan program PP.

\section{HASIL DAN PEMBAHASAN}

Ruslan (2006:26) menyebutkan peranan dari Public Relations adalah sebagai berikut. Pertama, Communicator (penyampai pesan); jika hal tersebut dikaitkan dengan peranan Media Relations dalam upaya pensosialisasian Program Provocative Proactive yang dilakukan oleh Departemen Promosi maupun oleh Bidang Humas (PR) dan dengan dilengkapi bahan-bahan dari Produser, dengan peranan PR sebagai penghubung pada tataran internal Metro TV maupun dengan pihak eksternal Metro TV, yaitu media massa dan pemirsa TV, jawaban wawancara dengan Bapak Yongky Yohansyah dan Ibu Henny Puspitasari menyatakan bahwa melalui tugas mereka untuk menjalin hubungan yang serasi dengan media massa melalui wartawan maupun dengan barter promosi dan menjaga hubungan baik dengan pemirsa melalui majalah, radio, dan Internet, media relations pihak Metro TV telah berbuat banyak terhadap program tayang Provocative Proactive (PP) agar dikenal luas oleh masyarakat. Pihak Public Relations akan selalu menerima dan mengumpulkan masukan dari audience (pemirsa dan masyarakat umum). Terkait hal ini, karena kegiatan Promosi dari Departemen Promosi Metro TV maupun PR Metro TV juga membuat blog/portal www. MetroTVNews.com, hal tersebut telah sesuai dengan hasil wawancara: "Masukan yang disampaikan melalui audience service/blog/portal, email, twitter, dan Facebook serta harian Media Indonesia yang dianggap membangun dari pemirsa akan diteruskan dan didiskusikan dalam rapat internal dengan pihak manajemen.” Dikaitkan dengan teori bahwa beberapa macam tujuan dari Hubungan Media adalah untuk memperoleh publisitas seluas mungkin dan untuk memperoleh tempat dalam pemberitaan media maupun untuk memperoleh umpan balik dari masyarakat, maka kegiatan Metro TV terkait dengan penyebarluasan info tentang program siarannya termasuk program PP memang telah terpenuhi.

Kedua, penyangga kegiatan manajemen (back-up management); peran kegiatan promosi agar program siaran yang didukung oleh Departemen Promosi maupun Bidang Humas (PR) dan dengan bantuan pihak Produser dapat dikenal luas, baik untuk kalangan internal maupun terlebih-lebih untuk kalangan eksternal, hal tersebut memang telah dilaksanakan. Hal itu sesuai dengan jawaban kedua narasumber atau responden yang menyatakan: "Peran sebagai media relations yang telah ditunjukkan Departemen Promosi Metro TV maupun Bidang Humas, baik secara internal sebagai penghubung yang terkait dengan program siaran maupun logistik dan dengan media massa lain seperti media cetak dan elektronik, berdasarkan wawancara kepada pihak terkait memang telah mengacu pada upaya untuk mensosialisasikan program tersebut semaksimal mungkin. Ditambah lagi dengan adanya akun twitter dari tiap-tiap host, hal itu sudah merupakan promosi tersendiri.”

Ketiga, menjaga citra perusahaan; Metro TV sebagai stasiun TV yang berinti berita, dan menayangkan berbagai program untuk kemajuan masyarakat termasuk dunia politik, sosial, ekonomi, budaya, sentilan membangun untuk berbagai kalangan, maka Bidang Humas Metro TV melalui respondennya menyatakan: "Kami, dengan dukungan Departemen Promosi, juga telah berupaya untuk menjalin kerja sama dengan berbagai media, baik melalui konferensi pers, press release, barter tayangan promosi, dan sebagainya, semuanya itu juga merupakan upaya untuk menjaga citra perusahaan agar tetap positif di mata umum. Di sinilah peran PR dalam hal media relations dengan berbagai pihak terkait, termasuk sosialisasi penayangan Program PP.

Berdasarkan kajian teori tentang hubungan media, Vivian (2008), menyatakan bahwa media relations yang dilakukan oleh Unit Kerja PR merupakan penugasan yang cukup penting karena perlu menjangkau kebutuhan yang bersifat internal maupun eksternal. Kebutuhan internal adalah untuk 
menjalin komunikasi yang rapi dengan segenap karyawan yang ada di perusahaan tersebut tentang berbagai informasi yang perlu diketahui. Sedangkan kebutuhan yang bersifat eksternal adalah kebutuhan untuk menjalin kerja sama dengan pihak terkait serta masyarakat umum. Jika hal itu dikaitkan dengan kegiatan yang selama ini telah dilakukan oleh Bagian Humas (PR) dari Metro TV dalam upayanya untuk mensosialisasikan Program Tayangan PP, hal itu sebenarnya telah cukup memadai berdasarkan jawaban dari para responden penelitian.

Terkait dengan strategi yang perlu ditempuh dalam hal pemilihan media massa yang dapat mendukung upaya sosialisasi program tayang PP serta pesan-pesan membangun yang ada dalam isi program siaran TV tersebut, maka pihak PR Metro TV sendiri telah merencanakan hal ini. Sesuai dengan hasil wawancara kedua narasumber yang menyatakan: "Tentang pemilihan media massa yang akan diajak bekerja sama kami telah memikirkan dan merancang media massa mana yang akan dilibatkan baik dengan promosi on-air oleh Metro TV sendiri maupun dengan cara barter promosi dengan media massa lainnya, termasuk upaya penulisan yang tepat dengan cara menjalin kerja sama dengan para wartawan media massa tersebut, misalnya dengan mengadakan press conference dan press release.” Agar program tayangan PP dikenal luas oleh masyarakat, Humas Metro TV telah melaksanakan berbagai upaya atau kegiatan dengan menjalin kerja sama dengan berbagai media cetak dan elektronik. Hal itu disebutkan oleh ketiga responden dalam hasil wawancara mereka, termasuk Manajer PR Metro TV, Ibu Henny Puspitasari.

Dalam hal ini Unit Kerja PR Metro TV maupun Departemen Promosi tidak sekadar mengeluarkan semacam berita atau bahkan iklan dan barter promosi kepada media massa. Namun mereka juga memiliki kemampuan teknis untuk menjalankan hubungan media (media relations) tersebut termasuk melalui jaringan dalam dunia maya atau Internet. Untuk itulah Metro TV mempunyai www.metrotvnews.com. serta beberapa jaringan via Internet lainnya untuk dapat menangkap aspirasi publik di samping melalui kerja sama dengan media cetak lainnya seperti surat kabar, majalah, dan melalui radio Hard Rock FM, Jakarta.

Iriantara (2008) memandang bahwa jika suatu organisasi memasuki tahap yang matang, dikenal luas oleh masyarakat dan selalu dinantikan kehadirannya, keingintahuan publik menjadi semakin besar. Reputasi menjadi makin menonjol bagi organisasi tersebut sehingga publik masih tetap memercayai organisasi tersebut. Di sinilah arti penting - bahkan sangat penting - kegiatan media relations yang harus dijalankan oleh suatu organisasi yang tidak hanya untuk kepentingan internal perusahaan itu tetapi juga untuk kalangan internal seperti pelanggan, dan pejabat pemerintah.

Tentang betapa pentingnya kedudukan PR suatu organisasi, Mantan PRO Universitas Wisconsin-River Fall, Barbara Averill (dalam Iriantara, 2008) mengemukakan bahwa tugas PR untuk mengembangkan media relations, meskipun hanya merupakan salah satu bagian dari Public Relations, hal itu dapat menjadi suatu perangkat yang penting dan efisien. Karena begitu mereka dapat menyusun pesan yang dapat diterima oleh media lokal, mereka sesungguhnya telah membuat suatu langkah yang besar menuju keberhasilan programnya. Di situ terlihat bahwa Averill telah menyamakan media relations dengan publisitas. Jadi dengan adanya jalinan kerja sama Metro TV dengan media massa, hal itu berarti sudah mempromosikan organisasi melalui media massa. Hal itu jelas sudah dilaksanakan oleh Metro TV sehubungan dengan kegiatan PR untuk mempromosikan program-program siaran termasuk program PR yang dikemas dalam sebuah obrolan Warung Kopi. Pemainnya memerankan pihak-pihak yang mempunyai posisi penting di masyarakat termasuk pada kelompok lapisan bawah/marjinal sebagai kritik membangun di segala bidang. Siaran tersebut diharapkan tidak hanya menjangkau orang dewasa tetapi juga kalangan remaja yang jumlahnya cukup besar. Sehingga dalam dialognya, selain mengupas hal-hal yang berbau politik, juga ada hal-hal keseharian yang terasa kocak dan menggelitik namun juga perlu perbaikan. PR Metro TV juga telah berupaya untuk menunjang kegiatan community relations dan customer relations atau investor relations dengan menjalin kerja sama dengan berbagai pihak. 
Salah satu kerja sama yang dilakukan oleh Departemen PR dan Departemen Promosi adalah menjalin kerja sama dengan para wartawan dengan melalui suatu pertemuan berkala yang disebut konferensi pers maupun secara lumintu dengan mengeluarkan press release. Di lain pihak pertemuan berkala yang diadakan dengan pihak Produser dan Tim Kreatif juga mempunyai pengaruh yang besar untuk perbaikan kualitas siaran. Pertemuan berkala tersebut termasuk untuk mendatangkan bintang tamu atau narasumber yang kompeten terkait dengan topik pembicaraan pada segmen tayangan. Maka dengan jalinan kerjasama Departemen Promosi dan Departemen PR, hal tersebut dapat diwujudkan karena kedua Departemen itu yang melakukan pembicaraan atau mengundang pihak luar. Dengan demikian, jelas bahwa karena tugas dan fungsi PR sebagai motor untuk terjalinnya kerja sama baik dengan pihak eksternal maupun internal yang terkait dengan program tayang PP, Unit Kerja atau Departemen PR dan Departemen Promosi ternyata juga membantu suksesnya program siaran PP, selain berbagai peran dan kerja keras Produser PP serta Tim Kreatif.

\section{SIMPULAN}

Berdasarkan hasil pengamatan atau observasi terhadap Peran Departemen PR dan Promosi Metro TV dalam melaksanakan kegiatan media relations melalui jalinan kerja sama dengan berbagai media-cetak dan elektronik dalam upaya agar program siaran Provocative Proactive ("PP”) dapat dikenal luas oleh masyarakat, dapat disimpulkan hal-hal sebagai berikut.

Jalinan kerja sama dengan berbagai media massa; Humas atau Unit Kerja PR Metro TV dan Departemen Promosi sebagai Unit Kerja dalam organisasi Metro TV telah melaksanakan berbagai macam cara agar Program "PP" dikenal secara luas di masyarakat. Cara-cara yang ditempuh itu antara lain menjalin kerja sama yang saling menguntungkan dengan berbagai media massa, melakukan barter promosi, press-release, pers conference, membuat blog/portal Internet, melayani berbagai kepentingan untuk pihak internal maupun eksternal, dsb. Di lain pihak melalui kerja keras, Produser PP dan Tim Kreatif juga telah melakukan kegiatan hubungan media melalui pertemuan berkala dengan kedua departemen untuk mencari masukan guna perbaikan kualitas tayangan. Ditambah lagi dengan adanya akun twitter masing-masing pemerannya (host) di Internet, hal itu juga merupakan semacam hubungan media yang baik (promosi) dengan para pemirsa sekaligus juga dengan media massa.

Penerapan strategi pemilihan media massa;_PR Metro TV maupun Bidang Promosi dalam strateginya untuk pemilihan media massa sebagai mitra kerjanya tidak melakukan tindakan diskriminasi. Artinya, semua pihak yang dapat diajak bekerjasama akan dilibatkan dan disesuaikan dengan segmen penayangan, segmen bisnis, dan sebagainya. Jadi dalam hal ini, Unit Kerja PR dan Bidang atau Departemen Promosi telah melakukan langkah-langkah agar Metro TV dapat mengajak berbagai macam stakeholder termasuk sponsor, pemasang iklan, dan media massa cetak maupun elektronik dengan menggarisbawahi upaya yang saling menguntungkan.

Pengenalan Program PP secara luas; Program Provocative Proactive merupakan program yang dewasa ini makin diminati oleh masyarakat karena masyarakat saat ini sudah makin haus terhadap persoalan-persoalan yang berbau politik, kritik membangun. Sekarang pemikiran kritis untuk meningkatkan kesejahteraan masyarakat makin menonjol, untuk itu pihak Metro TV telah berupaya mengemas program PP agar dapat menjangkau berbagai lapisan masyarakat, termasuk dari kalangan masyarakat golongan ekonomi lemah, menjangkau para remaja yang merupakan harapan bangsa. Maka PR Metro TV dan Bidang Promosi Metro TV telah dengan gencar menyebarkan press-release maupun pers conference serta tayangan iklan spot on-air dan off-air agar program PP semakin dikenal luas termasuk kerja sama dengan media cetak seperti majalah, surat kabar maupun media radio yaitu Radio Hard Rock FM di Jakarta, barter promosi dengan berbagai media dan melalui akun twitter para pemerannya (host). 


\section{Saran}

Seperti halnya program-program siaran lainnya, maka Program PP terus ditingkatkan kualitasnya, dikemas dengan baik agar lebih dikenal luas dan lebih diminati oleh para pemirsa di seluruh penjuru tanah air. Jadi dalam hal ini PR Metro TV maupun Bidang atau Departemen Promosi termasuk Produser PP dan Tim Kreatif diharapkan bekerja lebih profesional agar Program PP dapat lebih mengena dan dapat menjadi mimbar untuk menangkap aspirasi perbaikan terhadap kelemahankelemahan atau kesalahurusan di tanah air.

Suatu program siaran tidak hanya dikehendaki untuk dapat dikenal secara luas di masyarakat, tetapi juga kualitasnya perlu ditingkatkan, ada variasi tema yang bersifat serius namun juga ada hal-hal yang menghibur. Jadi selain rate \& share meningkat, namun tetap saja Produser siaran tersebut dan jajarannya (Tim Kreatif dan Kru) perlu berupaya agar minat masyarakat makin meningkat untuk menonton tayangan tersebut dengan berbagai metode atau cara. Pertemuan berkala dengan pihak lain untuk membahas materi siaran perlu diteruskan dan ditingkatkan, termasuk menghadirkan bintang tamu atau narasumber yang berbobot. Di samping itu, tentu saja ada unsur-unsur hiburan sebagai daya tarik tersendiri.

\section{DAFTAR PUSTAKA}

Burhan, B. 2007. Penelitian Kualitatif: Komunikasi, Ekonomi, Kebijakan Publik dan Ilmu Sosial Lainnya. Jakarta: Kencana Prenada Media Group.

Iriantara, Y. (2008). Media Relations: Konsep, Pendekatan, dan Praktik. Bandung: Simbiosa Rekatama Media.

Ruslan, R. (2006). Manajemen Public Relation dan Media Komunikasi. Bandung: Rosda Karya.

Sendjaja, S. D. (2002). Teori Komunikasi. Jakarta: Pusat Penerbitan Universitas Terbuka.

Sugiyono. (2009). Metode Penelitian Kuantitatif, Kualitatif, dan R\&D. Bandung: Alfabeta.

Vivian, J. (2008). The Media of Mass Communication. New Jersey: Pearson. 